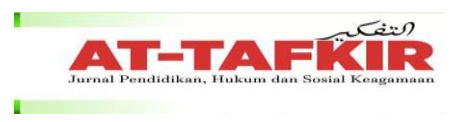

VOLUME 14 NOMOR 1 TAHUN 2021

P-ISSN : 1979-9357

E-ISSN : 2620-5858

\title{
Pola Interaksi Edukasi dalam Genelogy Tradisi Keilmuan Jami'al-Azhar
}

\author{
Zulfahmi $^{1}$, Asyraf Isyraqi Jamil ${ }^{2}$, Fakhrul Adabi Abdul Kadir ${ }^{3}$ \\ Universitas Serambi Mekkah, Aceh ${ }^{1}$. Universiti Malaya ${ }^{23}$ \\ zulfahmi@serambimekkah.ac.id ${ }^{1}$, isyraqi@um.edu.my², fakhruladabi@um.edu.my
}

\begin{abstract}
This article discusses Jami 'al-Azhar as a center for the knowledge study and the holistic interaction of teacher-student relationships. On the other hand, the position of teachers continues to be marginalized in the digital era. Hence, it is pivotal to look back at the teacher-student relationship that has prevailed in the history of Islamic education, especially in Jami 'al-Azhar. The research methodology employed literature review with a historical approach through primary and secondary source analysis. This study found that Jami 'al-Azhar was a center for the Islamic studies and study of science, initially aimed as propaganda for the Kingdom of Fathimiyah to perpetuate Shi'i understanding. However, the rank continued to develop to give a role as a center of thought and knowledge that gave birth to scholars from various schools of thought. One of its uniqueness as a center for the study of science is to perpetuate the interaction of teacher-student relationships in various traditions. Among the most prominent traditions are sanad, ijazah, suhbah, and talaqqi. Therefore, it can be concluded that the practice of teaching at Jami 'al-Azhar is manifested through the knowledge geneology and mentor system.
\end{abstract}

Keywords - Jami 'al-Azhar, Science Studies, Teacher-Student Relations, Tradition.

\begin{abstract}
Abstrak: Artikel ini membincangkan tentang Jami' al-Azhar sebagai pusat pengkajian ilmu dan interaksi hubungan guru-murid secara holistik. Di sisi lain, kedudukan guru yang terus terpinggirkan dalam era digital. Maka, perlu melihat kembali hubungan guru-murid yang telah berlaku dalam sejarah pendidikan Islam khususnya di Jami' alAzhar. Metodologi penelitian menggunakan kajian kepustakaan dengan pendekatan sejarah melalui analisis sumber primer dan sekunder. Kajian ini mendapati bahawa Jami' al-Azhar merupakan pusat pengajian dan pengkajian ilmu, pada awalnya bertujuan sebagai propaganda Kerajaan Fathimiyah bagi mengekalkan fahaman Syi'ah. Namun, peringkat seterusnya berkembang memberikan peranan sebagai pusat pemikiran dan ilmu pengetahuan yang melahirkan ulama-ulama dari pelbagai mazhab. Salah satu keunikannya sebagai pusat pengkajian ilmu adalah mengekalkan interaksi hubungan guru-murid dalam pelbagai tradisi. Antara tradisi yang sangat menonjol ialah sanad, ijazah, suhbah, dan talaqqi. Sehingga dapat dirumuskan bahawa amalan pengajaran di Jami' al-Azhar diwujudkan menerusi geneologi keilmuan dan sistem mentor.
\end{abstract}

Kata kunci-Jami' al-Azhar, Hubungan Guru-Murid, Kajian Ilmu, Tradisi.

\section{PENDAHULUAN}

Jami' al-Azhar merupakan sebuah institusi pendidikan yang sudah tua dan keberadaannya masih eksis sampai saat ini dalam mewarnai peradaban Islam. Pada awalnya, institusi ini dibangun pada masa Daulah Fathimiyyah dan pengelolaanya berbeda generasi. Pada saat itu, masjid jami' merupakan salah satu lembaga yang bergerak pada jalur pendidikan dan pengajaran, demikian pula dengan masjid Jami' al-Azhar. Keunikan al-Azhar dari berbagai segi terus dibicarakan, misalnya dari segi arsitek masjid al-Azhar (Rabbat, 1996), revolusi (Daniel Crecelius, 1966: 3149), Bibliografi (Gubara, 2012), peranan dalam politik (Zeghal, 1999), maupun peran Syeikh al-Azhar (Albo \& Meital, 2014) itu sendiri, bahkan perbincangan berkenaan pelajar Nusantara yang belajar di al-Azhar baik dari Malaysia (Abu Hanifah Haris, 2014: 15-31), Indonesia,(Abaza, 1991) Thailand dan negara-negara Asia lainnya.

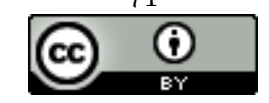

This work is licensed under a Creative Commons Attribution 4.0 International License 
VOLUME 14 NOMOR 1 TAHUN 2021

P-ISSN : 1979-9357

E-ISSN : 2620-5858

Peranan Jami' al-Azhar tidak dapat diabaikan dalam membina dan membangun generasi Islam. Hal ini bertujuan untuk memastikan kecemerlangan ilmu pengetahuan dan kemajuan umat Islam dengan tradisi-tradisi yang unik. Realita ini tidak terlepas daripada intelektual dunia Islam yang ada di Jami' alAzhar hari ini. Kenyataan tersebut dibuktikan melalui berbagai karya ulama salaf maupun kontemporer yang dipandang sebagai rujukan utama dunia Islam. Karyakarya tersebut dicetak dan disebarluaskan ke seluruh dunia, tidak terkecuali di Nusantara semisal Sullam al-Mubtadi', Hidayah al-Salikin, Dhau al-Siraj, Siraj al-Huda, dan lain-lainnya (Abu Hanifah Haris, 2014: 16-19). Al-Azhar sendiri menumpukan kajian dan penerbitan para ilmuwan dari semasa ke semasa sehingga perlu ditelusuri peranan dari segi sejarah peradaban dan pendidikan Islam.

Dengan demikian, Jami' al-Azhar sebagai pusat pengkajian ilmu harus digali kembali untuk melihat bagaimana sebenarnya interaksi edukasi antara gurumurid dalam membentuk suasana ilmiah dalam sejarah pendidikan Islam. Maka, secara tidak langsung kedudukan guru dapat dikembalikan marwahnya agar dapat disesuaikan untuk menjawab persoalan peranan guru di era digital.

Kontribusi yang dilakukan al-Azhar bertujuan untuk menjaga kedudukan ilmu pengetahuan sebagaimana awal era Islam, Rasulullah SAW. menjadi rujukan utama bagi masyarakat Islam sebagai delegasi yang autoriti (Balwi et al., 2018). Maka tidak dapat dinafikan, bahwa perkembangan ilmu pengetahuan juga menunjukkan kedudukan guru (ulama) itu sendiri. Kedudukan tersebut tidak terlepas daripada interaksi hubungan guru-murid dengan tanggung jawab ilmiah yang terus dijaga dan diamalkan. Oleh karena itu, pusat pengkajian ilmu di Jami' al-Azhar patut ditelaah keunikan interaksi hubungan guru-murid, apakah ia mempunyai asas falsafah dalam praktik pengajaran dan pembelajaran di institusi tersebut. Sehingga dapat dipastikan interaksi guru-murid dapat membentuk hubungan yang kuat dan kukuh sebagai tradisi dalam sejarah pendidikan Islam.

\section{METODE PENELITIAN}

Penelitian ini merupakan penelitian kualitatif. Instrumen pengumpulan data yang dijalankan adalah penelitian kepustakaan (library research) untuk mendapatkan bukti yang konkrit. Antara lain adalah kitab-kitab sarjana Islam seperti al-Khitat karya al-Maqriziy, al-Kamil fi al-Tarikh oleh Ibn 'Asir, Wafayat al-'Ayan wa Anba' alZaman oleh Ibn Khalikan, Tabaqat al-Shafi'yyah al-Kubra oleh Taj al-Din al-Subkiy, alBidayah wa al-Nihayah oleh Ibn Kathir, dan Siyar Al-'Alam Al-Nubala'karya al-Dhahabi. Semua kitab tersebut banyak memberikan data penting tentang sejarah pendidikan Islam di Jami' al-Azhar, khususnya tentang interaksi guru-murid dalam pengajaran dan pembelajaran. Sedangkan sumber skunder ialah data-data yang mendukung sumber primer.

Analisis data yang digunakan dalam penelitian ini adalah metode sejarah. Metode sejarah (historical method) merupakan proses analisis dan penilaian data atau rekaman sejarah secara kritis (Barry Gower, 1997: 15). Tujuannya untuk mendapatkan gambaran yang jelas mengenai sesuatu peristiwa, perkembangan dan pengalaman yang sudah berlaku, sekaligus amat penting bagi mengumpul dan menentukan bukti serta fakta secara sistematik dan objektif (Gillbert J. Garraghan, 1946; Mohd. Majid Konting, 1994: 87). Menurut 'Abd al-Rahman Badawiy (1977:

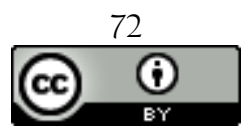

This work is licensed under a Creative Commons Attribution 4.0 International License 
VOLUME 14 NOMOR 1 TAHUN 2021

P-ISSN : 1979-9357

E-ISSN : 2620-5858

188-214), tahapan yang digunakan dalam penelitian sejarah yaitu mengenal pasti dokumen (al-watsa'iq) sejarah, membuat kritikan internal dan eksternal (al-naqd alkharijiy wa al-naqd al-batin), analisis (tahlil), interpretasi (tafsir) dan mendapatkan natijah (nata'ij). Dengan demikian, analisis data yang didapatkan dari berbagai rujukan perpustakaan dititikberatkan tentang data sejarah Jami' al-Azhar dari segi pengkajian ilmu dan interaksi edukasi guru-murid. Kemudian diberikan penilaian, dianalisis serta diberikan pentafsiran sesuai pandangan-pandangan yang mendukung data tersebut.

\section{HASIL DAN PEMBAHASAN}

Hasil penelitian ini disajikan dalam bentuk gambaran yang berlaku dalam sejarah pendidikan Islam di Jami' al-Azhar dari segi pengkajian ilmu dan interaksi hubungan guru-murid. Dari segi pengkajian ilmu akan dibahas tentang sejarah pendirian Jami' al-Azhar dan perannya sebelum abad 12 masehi. Sementara interaksi hubungan guru-murid diuraikan mengenai bentuk-bentuk interaksi yang dipraktikkan ketika berlangsung proses pengajaran dan pembelajaran ataupun di luarnya, tetapi mereka tetapi berinteraksi antar sesama.

\section{Sejarah Pendirian Jami' al-Azhar}

Islam di Mesir berawal pada tahun $20 \mathrm{H}$ atau $640 \mathrm{M}$ masa Khalifah Umar ibn al-Khattab menggelarkan misi futuhat (Rozali \& Rahman, 2017) ke wilayahwilayah dakwah Islam melalui penaklukan yang dipimpin oleh Amr bin Ash. Kaum Muslimin membangun masjid untuk kepentingan dakwah dan penyebaran agama Islam semata. Sebagaimana Masjid al-Amru yang dibina oleh Amr bin Ash pada tahun $21 \mathrm{H}$ sepulangnya dari Iskandariah. Masjid ini merupakan masjid tertua di Mesir yang dibangun kaum muslimin untuk majelis-majelis ilmu seperti pengajaran bahasa dan ushuluddin, walaupun juga menjadi lembaga politik dan kemasyarakatan (Ali Ibrahim Hasan, 1963: 91-93). Terdapat juga pembangunan masjid dalam ukuran yang besar untuk menampung sejumlah pasukan seperti Masjid Ibn Thulun yang didirikan pada tahun $263 \mathrm{H}$ oleh Ahmad Ibn Thulun dan merupakan masjid ketiga di Mesir.

Masa di antara pembangunan Masjid al-Amru dan Masjid Ibn Thulun didirikanlah Masjid Jami' al-Azhar. Menurut Mohammad al-Shallabi dalam alDaulah al-Fathimiyyah, al-Azhar didirikan oleh Jauhar al-Shiqili pada tahun $361 \mathrm{H}$ (Al-Shallaabi, 2006: 69). Secara lebih rinci, Ali Hasan Ibrahim menyebut bahwa Jami' al-Azhar mula dibina pada hari Sabtu, 4 Ramadhan 359 H/970 M dan selesai pembangunannya selama dua tahun, tepat pada 7 Ramadhan 361 H/972 M dimulai shalat untuk pertama kalinya. Sehingga Jami' al-Azhar dikenal sebagai masjid yang paling awal di Kairo dan tersohor dalam dunia Islam. Juga merupakan jami' terbesar dalam pengajaran al-ulum al-diniyyah wa al-aqliyyah sehingga berkumpul para murid dari berbagai pelosok negeri di seluruh dunia (Ali Ibrahim Hasan, 1963: 95; Ibn Khalikan, 1978: 380).

Dari segi penamaan Jami' al-Azhar, para ahli sejarah berbeda pandangan, sebagian menyatakan ia dikelilingi oleh keindahan istana pada awal pembangunan kota Kairo. Sebagian lainnya mengatakan penamaan al-Azhar untuk menunjukkan sikap optimis yang menjadi keinginan dan cita-cita besar bagi kehebatan ilmu 


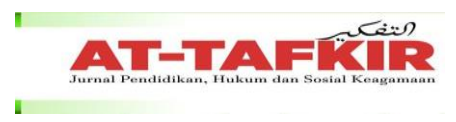

VOLUME 14 NOMOR 1 TAHUN 2021

P-ISSN : 1979-9357

E-ISSN : 2620-5858

pengetahuan. Di samping itu Daulah Fathimiyyah menamakan al-Azhar adalah menzahirkan nisbah sempena nama puteri Rasulullah SAW. Fatimah al-Zahra (Ali Ibrahim Hasan, 1963: 95). Manakala segi letaknya Masjid Jami' al-Azhar berada di Tenggara kota Kairo di dekat Istana Agung yang dahulu terdapat antara Kampung Dailam dan Kampung Turk di selatan.

Ketika Daulah Fathimiyyah berkuasa, nas-nas tulisan yang dilukis oleh Jauhar di sekeliling kubah masjid tersebut telah dihilangkan. Bahkan diperintahkan tidak memakai khutbah yang memuja Bani Abbas dan juga diharamkan memakai jubah hitam sebagai simbol Bani Abbasiyyah sehingga diganti dengan pakaian putih. Lafadh azan diganti dengan "haiya ala khairil "amal" serta disuruh dalam khutbah diucapkan: "Ya Allah ucapkan shalawat atas Nabi Muhammad, manusia yang terpilih, kepada Ali, manusia yang diridhai, kepada Fatimah, manusia yang berpisah diri menyembah Tuhan dan kepada Hasan dan Husen (cucu Rasulullah), mereka itu disucikan Allah dari kekotoran dan disucikan. Serta shalawat atas diri imam-imam yang suci, ayah-ayah dari Amirul Mukminin, al-Muiz Li Dinillah". Dengan demikian seruan doa atas Bani Abbas di Mesir, Hijaz, Yaman dan Syam terhenti dengan sendirinya. Doa yang dipakai pada masa itu ialah atas Bani Ubaid hingga tahun 565 H (Ibn Khalikan, 1978: 379; AlDhahabi, 1973: 160-164). Namun demikian, al-Azhar tetap mempunyai kedudukan yang mulia di dunia Islam, karena ia merupakan cahaya ilmu pengetahuan dan tempat bertapak murid-murid yang terus belajar dan mengkaji sepanjang sejarah sampai datang masa Kerajaan Bani Ayyub. Bani Ayyub memerangi golongan Syi'ah dan menyiarkan mazhab Sunni, khutbah di al-Azhar dibatalkan dan hanya diadakan di Masjid al-Hakim sesuai dengan mazhab Syafi'i (Su'ad Maher, n.d.: 89).

Tujuan al-Azhar didirikan ditengah-tengah kekuasaan Fathimiyyah seiring dengan cara mendirikan fundamental Islam yang pertama. Masjid al-Azhar dijadikan masjid rasmi bagi Kerajaan Fathimiyyah di ibu kota yang baru (Kairo). Tidak lain tujuannya sebagai mimbar untuk propaganda agama dan simbol kekuasaan rohaninya (Su'ad Maher, n.d.: 8-9). Sementara ide untuk mengadakan pelajaran di Jami' al-Azhar adalah suatu kejadian yang timbul daripada gagasan mazhab yang berangsur mempengaruhi keadaan di masa itu. Kemudian berubah sifatnya yang awal untuk menjadikan al-Azhar sebagai sebuah Jami'ah (universitas). Ali Basha Mubarak menyebutkan bahwa pemimpin yang memulai bacaan-bacaan ilmu di Jami' al-Azhar dan ia termasuk permulaan pengajaran ilmu yaitu pada tahun 380 H. Di mana sebelumnya, wazir Ya'qub ibn Killis (318-380 H/930-991 M) (Abu Fida' Ismail Ibn Kathir, 1997: 436; Al-Dhahabi, 1984: 442; Ibn Khalikan, 1978: 27), mengadakan majlis-majlis ilmu di rumahnya dengan mengundang para fukaha' dan mutakallim untuk membacakan kitab-kitab fiqh dalam Mazhab Fathimiyyah (Ali Basha Mubarak, 1306H: 11). Sebenarnya pengkajian di Jami' al-Azhar dimulai dengan halaqah ilmu pada akhir pemerintahan Al-Mu'iz Li Dinnillah (341-365 H/952-975 M) yang dipimpin oleh Qadi Al-2udat Abu al-Hassan Ali bin Nu'man al-Qayrawani, seorang ilmuwan ulung dari Maghribi pada bulan Safar 365 H/Oktober 975 M. Pengajaran dijalankan merujuk kepada kitab perundangan Islam yang bertajuk Al-Ikhtisar (fiqh ahl al-Bayt)

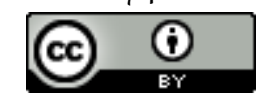

This work is licensed under a Creative Commons Attribution 4.0 International License 
VOLUME 14 NOMOR 1 TAHUN 2021

P-ISSN : 1979-9357

E-ISSN : 2620-5858

yang dihadiri oleh sejumlah para ulama dan sarjana Islam (Taqi al-Din Ahmad ibn Ali Al-Maqrizi, 1997: 156; Abu Fida' Ismail Ibn Kathir, 1997: 365-368).

Ketika Khalifah al-'Aziz Billah Nizar Abu Mansur (365-386 H/975-996 M) berkuasa, Ya'qub ibn Killis meminta beliau untuk meningkatkan status al-Azhar sebagai sebuah al-Jami'ah (universiti) yang dibiayai sepenuhnya oleh kerajaan dan beliau sendiri yang memimpin majlis munazarah ilmu di Jami' al-Azhar dengan mengkaji kitab fiqhnya al-Risalah al-Waziriyah (Muhammad al-Bahi, 1964: 16-17). Secara rasmi pula, Khalifah al-'Aziz membiayai 35 para fuqaha' untuk menjalankan pengajaran ilmu di al-Azhar. Khalifah juga membangun asrama-asrama sebagai kediaman para fuqaha', ulama dan pelajar serta diberikan beasiswa dengan pembiayaan penuh (Ibn Khalikan, 1978: 371-373).

Pengkajian dan pengajaran yang dilakukan ketika itu, menunjukkan kedudukan al-Azhar sebagai pusat Ilmu. Tetapi ia juga mempunyai kepentingan resmi sebagai tempat kedudukan Qadhi pada hari-hari tertentu dan sebagai pusat pembesar-pembesar kerajaan dengan diadakan sidang Khalifah dan sidang peradilan. Walaupun pada masa Bani Ayyub khutbah Jumat dibatalkan di Jami' alAzhar, sifatnya sebagai jami'ah senantiasa dijaga dengan kedudukan ilmiah yang telah ada. Sehingga Jami' al-Azhar tetap didatangi oleh para ulama yang tersohor seperti Abdul Latif al-Baghdadi yang datang ke Mesir pada tahun 589 H, di masa pemerintahan Raja Abdul Aziz, anak Sultan Salahuddin. Al-Baghdadi mengajar di al-Azhar beberapa tahun lamanya sehingga meninggal Raja Abdul Aziz pada tahun 595 H (Maher, n.d.: 10). Al-Azhar sebagai sebuah institusi pendidikan terus membuka ruang bagi pengkajian ilmu pengetahuan. Kehadiran para ulama untuk memberi pelajaran-pelajaran di Jami' al-Azhar menggambarkan suatu hubungan guru-murid yang harus diteliti lebih lanjut.

\section{Peran Jami' al-Azhar}

Menurut Al-Shallaabi (2006: 69), Jami' al-Azhar dibina oleh Jauhar alShiqili yang bertujuan menjadi mimbar kepada kaum al-Ubaidin al-Rawafidh bagi mensyiarkan keyakinan (akidah) mereka yang salah dan pemikiran mereka yang rusak, kemudian tiba masa Sultan Salahuddin al-Ayubi yang memberantas berbagai perkara yang bertentangan dengan aliran dan pemikiran Ahl al-Sunnah. Awal penubuhan Jami' al-Azhar lebih mengutamakan golongan Syiah seperti menghilangkan pujian-pujian kepada Bani Abbasiyyah dalam khutbah Jumat yang diganti dengan Shalawat ke atas Nabi Muhammad SAW serta Ahlu al-Bait dan imam-imam mereka, diubah lafadh azan kepada "hayya ala khairil amal". Disamping itu terdapat mazhab yang paling berpengaruh dalam pelajaran di al-Azhar iaitu pengajian kitab-kitab Syiah dan Fiqh Ahlu al-Bait ketika diadakan majelis ilmu, baik pada masa Khalifah al-Muiz Lidinillah maupun Khalifah al-Aziz Billah.

Semasa Sultan Salahuddin al-Ayubi memerintah ditubuhkan madrasahmadrasah lain dan mencapai bilangan yang sangat banyak pada abad ke VII dan ke VIII Hijrah. Beliau sendiri menubuhkan Madrasah al-Nasiriyyah di dekat Masjid Jami' Amru untuk mengajarkan fiqh Mazhab Syafi'i. Berdekatan dengan madrasah ini juga dibina Madrasah al-Qamhiyyah sebagai tempat memberi pelajaran fiqh Mazhab Maliki (Maher, n.d.: 11-12). Ertinya penubuhan madrasah-madrasah

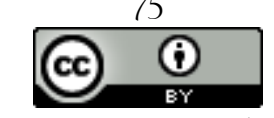

This work is licensed under a Creative Commons Attribution 4.0 International License 
VOLUME 14 NOMOR 1 TAHUN 2021

P-ISSN : 1979-9357

E-ISSN : 2620-5858

tersebut adalah mengikut keperluan dan berasaskan bidang-bidang tertentu sehingga dapat dikatakan semua mazhab wujud pada masa itu.

Penubuhan berbagai madrasah pada abad ke VII dan ke VIII memberi kesan yang sangat besar kepada Jami' al-Azhar, ia mesti bersaing untuk menarik para murid dan guru-guru yang tersohor. Kerana madrasah-madrasah itu dibina oleh Sultan dan pembesar-pembesar kerajaan dengan keistimewaan dan pembaharuannya, sementara Jami' al-Azhar terleka pada masa itu. Namun demikian, Jami' al-Azhar berbeza dengan madrasah-madrasah tersebut, ia mempunyai lapangan dan mata pelajaran yang beragam serta dibuka untuk murid dari seluruh kalangan mazhab baik ilmu agama maupun bahasa, yang tidak ada pada madrasah yang lain. Akhir abad ke VII madrasah-madrasah di Baghdad dan Cordova khususnya lenyap dari alam wujud, sehingga al-Azhar merupakan Ka'bah ilmu pengetahuan, menarik guru-guru dan murid-murid dari seluruh pelosok dunia Islam sebagai puncak pemikiran dan kebudayaan serta mencapai puncak kejayaan pada masa Kerajaan Mamluk (Maher, n.d.: 13).

Perkembangan Jami' al-Azhar dari awal pendiriannya sampai kepada abad seterusnya menunjukkan perubahan yang ketara sebagai pusat ilmu pengetahuan, sehingga dapat dilihat perannya seperti berikut:

\section{a. Pusat Pemikiran dan Ilmu Pengetahuan dalam Dunia Islam}

Sejak era Khalifah al-Hakim peran Jami' al-Azhar telah menjurus kepada penyampaian dan pengajaran ilmu-ilmu Islam bagi seluruh umat manusia, menyuburkan nilai-nilai kebudayaan Islam dan memelihara kemurnian bahasa arab sebagai bahasa utama dalam ajaran Islam dan sebagai bahasa akademik (Ahmad Sobri Salamon, 1988: 3; Ali Khitab 'Atiyyah, 1947: 150-154). Bahkan sejak kejatuhan Kerajaan Fathimiyyah dan berdiri Kerajaan Ayyubiyyah, diketahui bahwa al-Azhar sebagai Jami'ah yang merdeka dan bebas mengajarkan ilmu-ilmu akal dan ilmu-ilmu modern disamping ilmu-ilmu agama dengan cara yang sangat teratur. Misalnya, didapati guru-guru dari kalangan ulama seperti Abdul Latif alBaghdadi yang mengajar ilmu perubatan, falsafah dan logik (Maher, n.d.: 27).

Pada masa pemerintahan Khalifah al-Hakim bin Amr Allah (386-4ll H/9961020 M) merupakan era kegemilangan intelektual Islam di Mesir terutamanya di Jami' al-Azhar. Disamping memajukan Jami' al-Azhar beliau juga membina institusi-institusi penyelidikan, yang penting antaranya Dar al-Hikmah sepertimana Bayt al-Hikmah di Baghdad, setelah 35 tahun berdirinya Jami' alAzhar. Al-Hakim juga mementingkan pengkajian ilmu-ilmu naqliyah seperti perundangan Islam yang tidak terbatas kepada mazhab fiqh atau aliran pemikiran (Muhammad Abdullah 'Anan, 1958: 51-53; Taqi al-Din Ahmad ibn Ali Al-Maqrizi, 1997: 2nd ed. 334-337). Sehingga pada era pemerintahan al-Hakim pengkajian fiqih perbandingan mazhab sangat menonjol. Hal ini pula tidak terlepas daripada hubungan guru atau ulama dalam memberikan pengajaran kepada muridmuridnya yang telah diletakkan sejak awal pengajaran ilmu di Jami’ al-Azhar.

\section{b. Menghimpun Para Guru dan Murid dari semua kalangan}

Majelis ilmu di Jami' al-Azhar dimulai dengan cara lama yang dilakukan di Mesir dan kota-kota Islam lainnya yang telah dikenal sejak abad kedua hijrah. Majelis ilmu diatur dengan baik, guru duduk ditengah-tengah majelis yang dikelilingi oleh murid-murid yang terkumpul dalam satu udara yang sederhana,

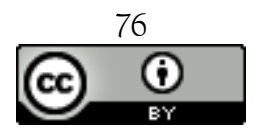

This work is licensed under a Creative Commons Attribution 4.0 International License 


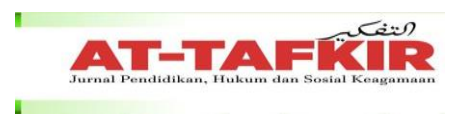

VOLUME 14 NOMOR 1 TAHUN 2021

P-ISSN : 1979-9357

E-ISSN : 2620-5858

namun memberi ruang yang besar bagi mereka untuk berdebat dan bertukar pikiran secara bebas dan leluasa. Maka, tidak hairan apabila Menteri Yackub ibn Killis memberi pelajaran langsung dalam majelis ilmu itu, bahkan beliau meminta Khalifah al-Aziz Billah untuk menyediakan gaji dan tempat tinggal bagi para ulama yang mengajar di sana.

Banyak guru-guru yang tersohor mengajar di al-Azhar, antaranya Bani Nu'man dan para Qadhi di Mesir. Abu al-Hasan ibn Nu'man (m. 374 H) yang faqih dan mahir dalam Fiqh Ahlu al-Bait, saudaranya Muhammad ibn Nu'man (m. 389 H) dan anaknya al-Husein ibn Nu'man sebagai Qadhi al-Hakim bi Amrillah juga mengajar di Jami' al-Azhar. Ada juga ahlu al-fiqh dan sejarah Mesir yaitu al-Hasan ibn Zaulaq (m. $347 \mathrm{H}$ ) yang merupakan kawan Khalifah al-Muiz Li Dinillah dan menulis riwayat hidup beliau. Terdapat juga dari kalangan sastera dan pujangga yang belajar dan mengajar di al-Azhar iaitu al-Amir al-Mukhtar 'Izz al-Malik Muhammad ibn Abdullah (m. $420 \mathrm{H}$ ) yang lebih dikenal dengan al-Misbahi, beliau pernah menjadi Menteri ketika Khalifah al-Hakim bi Amrillah. Beliau mendapat kedudukan yang istimewa disisinya dan mendapat bagian yang besar dari berbagai cabang ilmu pengetahuan yang berkembang pada masa itu (Abdul Aziz Muhammad Syanawi, 2013: 70).

Selain itu, ada juga di antara mereka yang mengajar di al-Azhar antaranya ialah Abu Abdullah al-Qudha'i (m. 454 H), seorang ahl al-fiqh, hadith dan ahli sejarah. Antara kitab-kitabnya yang terkenal ialah kitab al-Syihab dan kitab Musnad al-Shahab dalam ilmu hadith, kitab Anba' al-'Anbiya' dan kitab 'Uyun al-Ma'ariftentang ringkasan sejarah. Demikian juga dengan al-Hufi (m. 430 H) dengan nama Abu alHasan Ali ibn Ibrahim ibn Sa'id, seorang ahli bahasa yang mengarang kitab tentang nahwu dan sastera. Ibn Babasyad yang disebutkan namanya Abu al-Hasan Thahir ibn Ahmad al-Mishriy (m. 469 H), seorang ahli nahwu yang terkenal dan Abu Abdullah Muhammad ibn Barakat al-Nahwi (m. 502H), seorang ahli nahwu dan murid kepada al-Qudha'i. Bahkan sederet guru dan murid yang belajar dan mengajar di Jami' al-Azhar selama berabad-abad dari masa kerajaan yang berbedabeda (Abdul Aziz Muhammad Syanawi, 2013: 71).

\section{c. Melahirkan Ulama Mazhab dan Pejabat Negara}

Perkembangan Jami' al-Azhar tidak menekankan pengajaran satu mazhab saja, tetapi ia mencakup semua mazhab yang berkembang dalam Islam. Sejak memulai pelajaran, ia membuka pintu bagi siapa saja yang datang kepadanya dari seluruh pelosok dunia. Al-Azhar menampung murid-murid dari Mesir dan umat Islam yang menuntut ilmu serta diberikan kepada mereka bantuan beasiswa.

Realitas ini merupakan kesan dari naungan semua mazhab sehingga melahirkan ulama-ulama yang berbeda mazhab. Hal ini pula dapat dilihat bahwa rektor-rektor (Syeikh al-Azhar) dipegang oleh berbagai mazhab. Kalangan Mazhab Maliki seperti: Syeikh Muhammad Abdullah al-Khursyi al-Maliki (m. 1101 H), Syeikh Muhammad al-Nasyarti al-Maliki (m. 1120 H), Syeikh Abdul Baqi' alQalini (m. 1123 H). Dalam kalangan Mazhab Syafi'i pula ialah: Syeikh Abdullah alSyabrawi (m. 1171 H), Syeikh Muhammad ibn Salim al-Hifni al-Khalawati (m. 1181 H), Syeikh Abdul Rauf al-Sudjaini (m. 1182 H). Kalangan Mazhab Hanafi antaranya: Syeikh Muhammad al-Abbasi al-Mahdi al-Hanafi (m. 1315 h), Syeikh Hassunah al-Nawawi al-Hanafi, Syeikh Abdurrahman al-Nawawi al-Hanafi (m.

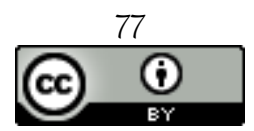

This work is licensed under a Creative Commons Attribution 4.0 International License 
VOLUME 14 NOMOR 1 TAHUN 2021

P-ISSN : 1979-9357

E-ISSN : 2620-5858

1317 H). Sementara dari kalangan Mazhab Hanbali tidak ada seorang pun yang menjabat jabatan rektor karena jumlah mereka yang sedikit dan sering terjadi perselisihan (Maher, n.d.: 42-49).

Dari segi pejabat negara juga ramai dihasilkan oleh Jami' al-Azhar antara mereka ialah qadhi dalam kalangan Bani Nu'man yang mendampingi Khalifah dalam urusan pemerintahan dan peradilan. Contoh lainnya Abu Abdullah alQudha'i yang menjadi qadhi semasa Khalifah al-Muntashir Billah (Syanawi, 2013: 70). Dapat dinyatakan bahwa ulama-ulama besar al-Azhar selain mengajar di Jami' al-Azhar juga menjabat jabatan penting dalam setiap pemerintahan dan period masing-masing kerajaan.

\section{d. Pelita bagi Ilmu dan Bahasa Arab}

Ketika terjadinya kekacauan dan keruntuhan kerajaan-kerajaan di Mesir, al-Azhar tetap menjadi pelindung terakhir bagi ilmu-ilmu agama dan bahasa. Ia menjadi benteng yang kokoh bagi bahasa Arab dan memelihara ruwak-ruwak para murid dengan segala kekuatan dan semangat yang luar biasa. Al-Azhar berusaha menghindarkan sebab-sebab keruntuhan yang dapat mengalahkan bahasa arab daripada masuknya bahasa pembuka negeri sampai bahasa asing sekalipun ke dalam masyarakat Mesir.

Khidmat yang sangat besar diberikan al-Azhar terutama pada masa gelap gulita dalam menjaga dan mengemukakan bahasa Arab. Ketika Kerajaan Turki Ustmani, Mesir menjadi tempat berlindung bagi para penuntut ilmu-ilmu Islam dan bahasa Arab dari negara-negara Arab disekitarnya (Maher, n.d.: 15). Kenyataan ini tidak dapat diketepikan begitu besar peran al-Azhar dalam menjaga ilmu Islam dan bahasa Arab sebagai penaung ilmu pengetahuan di seratau dunia dan Islam.

\section{e. Penaung Politik Tinggi Negara}

Setiap khalifah mengangkat para ulama yang mempunyai kedudukan dan pengaruh untuk mengisi jabatan Qadhi negara. Sehingga mereka memegang peran untuk mengendalikan dan memimpin umat agar tidak terjadi kekacauan. Bahkan pengaruh ulama dalam kerajaan mencapai kepada politik tinggi negara, ia menentukan nasib kerajaan dan sultan apabila terjadi sesuatu perkara yang tidak dapat dipastikan baik dari dalam maupun luar kerajaan. Seperti serangan kerajaankerajaan lain yang berusaha menghilangkan pengaruh al-Azhar dan ulamanya serta sultan-sultan yang bernaung dibawahnya.

Akhir abad ke IX gerakan kebudayaan di Mesir yang beragama Islam mulai padam karena turunnya kerajaan Mesir dan Kerajaan mamluk telah tua, mulai luntur ke jurang kemusnahan, perpecahan dan kegoncangan dalam kalangan masyarakat. Kerajaan Mesir jatuh dibawah serangan Kerajaan Turki Ustmani pada tahun $921 \mathrm{H}$, al-Azhar pun mengalami nasib yang sama. Walau bagaimanapun alAzhar tetap menjalankan tugas dan kewajiban yang besar yang dapat dilakukan. Sehingga tidak menghilangkan kedudukan, pengaruh dan kehormatan sebagaimana masa lampaunya yang ada dalam hati bangsa Turki sebagai pembuka Negeri Mesir. Mereka berusaha mengambil keberkahan dengan sering melaksanakan shalat di al-Azhar dan menjauhi perkara-perkara yang menimbulkan kerusakan. Mereka juga memberikan kedudukan yang istimewa kepada al-Azhar dan berusaha mempergunakan pengaruh ulama-ulama al-Azhar setiap berlaku peristiwa pemberontakan dalam negera (Maher, n.d.: 13-15). Hal ini 
VOLUME 14 NOMOR 1 TAHUN 2021

P-ISSN : 1979-9357

E-ISSN : 2620-5858

menunjukkan kedudukan al-Azhar dan ulama pada abad kesembilan sebagai pemberi pencerahan rohani-intelektual negara dan penjaga ummah (Gubara, 2012: 324).

Peran-peran yang telah digariskan di atas menunjukkan keutuhan Jami' alAzhar sebagai institusi pendidikan dan pusat ilmu pengetahuan yang diiktiraf oleh kerajaan yang berlama-lama abadnya. Ia tidak surut dengan berbagai goncangan dari mana jua, kegigihan para guru dan murid yang tetap istiqamah dalam keilmuan adalah tradisi yang sangat besar nilainya. Perkembangan tradisi keilmuan di Jami' al-Azhar menunjukkan kemuncak kegemilangan pada abad keempat dan kelima hijrah sebagai era keemasan pemikiran dan intelektual Islam. Hakikatnya era ini dapat memastikan pula pusat pengkajian ilmu yang tersohor dengan gerakangerakan ilmiah dan penyelidikan baik ilmu agama maupun sains. Bentuk kurikulum dan sistem pengajaran dan pembelajaran dipraktekkan sepanjang abad bahkan sampai hari ini. Secara tidak langsung telah menarik murid-murid dari seluruh penjuru dunia dan terus bertambah ramai dari tahun ke tahun.

\section{Kurikulum Jami' al-Azhar}

Kemunculan al-Azhar sebagai al-Jami'ah dan masjid pada akhir abad keempat telah memenuhi fungsi institusi pendidikan Islam yang menekankan seluruh ilmu berasaskan ilmu-ilmu wahyu. Ia telah menunjukkan dirinya sebagai sebuah universitas Islam tertua dan mampu bertahan dalam menghadapi berbagai tantangan. Ini terbukti ketika al-Azhar menyambut ulang tahunnya yang 1000 tahun pada tahun 1361 H/1942 M ('Anan, 1958: 10). Bahkan sampai hari ini ia tetap eksis walaupun terjadi berbagai pergolakkan besar di Arab atau Timur Tengah yang dikenal dengan "Arab Spring" yang memberi kesan terhadap perpolitikan Mesir secara menyeluruh (Hafez Ghanem, 2016: 39). Namun, al-Azhar mampu mempertahankan kurikulum pendidikan sehingga memenuhi cita-cita awal sebagai pusat ilmu, bahasa dan dakwah Islam secara menyeluruh dan mendalam ('Anan, 1958: 55-56). Keunikan dalam pengajaran dan pembelajaran dari segi kurikulum maupun perkara lainnya seperti hubungan yang ketara antara gurumurid sehingga ia bertahan ke abad-abad selanjutnya.

Menurut Muhammad Syanawi, semasa Fathimiyyah pengajaran di alAzhar dibentuk ke dalam beberapa peringkat: pertama pengajaran agama yang ditekankan kepada pengajian mazhab Syi'ah. Kedua, pengajaran agama melalui pengajian bahasa dan adab. Ketiga, pengajian berhalaqah iaitu halaqah pengajaran agama secara umum dan halaqah pengajaran mazhab secara khusus. Keempat, pengajaran belum menjurus kepada bidang dan manhaj yang ditetapkan sesuai pengakuan keilmiahan(Syanawi, 2013: 59). Sua'd Maher (n.d.) dan Shalabi (1954) melihat bahwa Jami' al-Azhar mengajarkan kedua-dua bidang keilmuan: pertama, ilmu-ilmu keagamaan (naqliyah) yang terdiri daripada tata bahasa dan kesusasteraan arab, tafsir al-Quran, al-hadith, fiqh, tauhid dan sejarah. Kedua, ilmu-ilmu yang berasaskan akal (aqliyah) seperti falsafah, logik, matematik, kejuruteraan, astronomi, perubatan dan lain-lain(Fadzlullah Hj. Shuib, 1995: 138; Maher, n.d.: 27; Muhammad al-Bahi, 1964: 274-275).

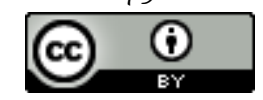

This work is licensed under a Creative Commons Attribution 4.0 International License 
VOLUME 14 NOMOR 1 TAHUN 2021

P-ISSN : 1979-9357

E-ISSN : 2620-5858

Kitab-kitab yang digunakan menjadi teks pengajaran dan pembelajaran yang meliputi berbagai bidang, antaranya ialah:

1. Kitab figh al-Ikhtisar yang disampaikan oleh al-Qayrawani.

2. Ikhtilaf Usul al-Madhahib (Perbezaan asas-asas mazhab).

3. Da'a'im al-Islam (Prinsip-prinsip Islam).

4. Al-Risalah al-Waziriyah, kitab yang disampaikan oleh Menteri Yackub ibn Killis.

5. Sirah Muhammad al-Ikhsyid, Sirah al-Muiz, Sirah al-Aziz, kitab sejarah yang ditulis oleh al-Hasan ibn Zulaq.

6. Astronomi dan fizik, karya-karya Ibn Yunus.

7. Tafsir al-Quran dan 'Ulum al-Quran, karya-karya al-Hufi.

8. Tata bahasa Arab, karya-karya Ibn Babasyad.

9. Optik, karya-karya Ibn Haitham.

10. Al-Hadith dan 'Ulum al-Hadith, karya-karya al-Qudha'i.

11. Qiraat (bacaan al-Quran), karya-karya al-Syatibi (Maher, n.d.: 28-30; Muhammad al-Bahi, 1964: 281-282; Syanawi, 2013: 70-71).

Beragam karya dan kitab-kitab tersebut kebanyakan adalah karya para ulama al-Azhar. Mereka yang mempunyai kepakaran dalam bidang tafsir, hadith, ilmu qira'at, ilmu bahasa dan adab. Mereka mengajar di al-Azhar dalam halaqahhalaqah ilmu baik secara langsung kepada murid-muridnya maupun tidak langsung. Kenyataan ini menunjukkan bahwa guru-murid mempraktikkan tradisitradisi yang berkesinambungan untuk meletakkan dasar yang kokoh dengan nilainilai falsafah yang tinggi. Al-Azhar bukan setakat pusat ilmu yang selalu eksis sepanjang abad, tetapi ia menanamkan nilai-nilai yang kuat baik secara lahir maupun batin. Hakikat ini ditemukan dalam hubungan guru-murid yang menggambarkan peradaban dan silsilah (genealogi) keilmuan dalam pendidikan Islam. Dengan demikian, pendidikan Islam yang bermuara kepada hubungan gurumurid merupakan suatu proses untuk memberikan output kepada perubahan sosial dan masa depan pendidikan. Kesan dan manfaat inilah seperti yang disarankan Lubis (2012: 107-108) untuk mewujudkan hubungan manusia. Dalam pendidikan Islam hubungan inilah sebagai dasar hubungan guru-murid yang selalu diamalkan di Jami' al-Azhar sehingga menunjukkan suatu peradaban dunia yang tetap terjaga.

\section{Interaksi Hubungan Guru-Murid di Jami’ al-Azhar}

Setiap institusi pendidikan memiliki cara tersendiri dalam mengayomi hubungan guru-murid untuk belajar mengajar dengan nyaman. Jami' al-Azhar telah mengamalkan sistem pengajaran dan pembelajaran yang unik dari sejak awal permulaannya. Guru duduk membaca pelajaran dalam satu lingkaran yang terdiri dari murid-murid dan para pendengar lainnya. Lingkaran ini pula diatur waktu dan tempatnya sesuai dengan bidang-bidang ilmu yang diajarkan. Misalnya guru fiqh, hadith, tafsir, nahwu maupun bidang lainnya diberikan tempat pada ruwak-ruwak atau ruang-ruangnya. Sehingga di hadapan guru, duduk para murid dan pendengar lainnya untuk memperhatikan pelajaran dan bertukar pikiran dengan guru tersebut tentang perkara-perkara yang diperlukan.

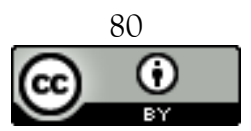

This work is licensed under a Creative Commons Attribution 4.0 International License 


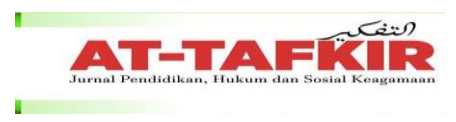

VOLUME 14 NOMOR 1 TAHUN 2021

P-ISSN : 1979-9357

E-ISSN : 2620-5858

Peraturan seperti ini senantiasa dipraktikkan di Jami' al-Azhar sepanjang masa lampau. Pada abad-abad pertengahan Jami' al-Azhar telah memberi kuliah dengan cara seperti itu bagi mengumpulkan guru pakar "Syeikh" dan murid-murid dalam ruwak-ruwak pengajaran yang ditetapkan. Apabila ditelaah dapat dianalisa bahwa adanya hubungan guru-murid dalam beberapa perkara merupakan nilai peradaban itu sendiri. Dengan demikian, hubungan guru-murid yang mencerminkan pengkajian ilmu dan peradaban pendidikan Islam pada Jami' alAzhar dapat digambarkan sebagaimana berikut:

\section{a. Tradisi Sanad}

Dalam pendidikan Islam, sanad merupakan aspek yang sangat penting untuk melihat keabsahan periwayatan dan memastikan kesahihan hadis yang disampaikan dan diperolehi oleh ilmuwan hadis. Tradisi ini telah ada sejak dahulu yang merujuk kepada silsilah keilmuan sebagai suatu hubungan yang terjalin antara guru-murid. Para ulama Islam menitikberatkan tradisi ini agar terjamin penyampaian dan perolehan ilmu yang sahih seumpama talaqqiy dan mushafahah (Jasmi \& Noh, 2013). Sufyan al-Thawriy menerangkan bahwa sanad merupakan senjata orang mukmin, sekiranya tidak ada senjata dengan apa mau berperang (membunuh). Al-Awza'iy juga menyatakan bahawa tidak akan hilang ilmu kecuali hilangnya sanad. Ahmad Ibn Hanbal pula berkata: mencari sanad yang lebih tinggi dejaratnya merupakan kewajiban (sunah) dalam kalangan salaf, sebagaimana yang dilakukan 'Abd Allah Ibn Mas'ud dan para sahabat pergi dari Kufah ke Madinah untuk belajar dan mendengar langsung daripada 'Umar.(Al-Qathan, 2007: 52; AlTahhan, 1985: 9-10; 181; Nur al-Din Itr, 1997: 55; 344).

Pengkajian ilmu di Jami' al-Azhar, tidak mengetepikan tradisi sanad. Seseorang murid mesti mendapatkan kebenaran ilmu dalam bidang-bidang yang diperolehinya. Proses pengajaran dan pembelajaran di Jami' al-Azhar memfokuskan dua bidang keilmuan baik itu ilmu agama (naqliyyah) mahupun ilmu akal ('aqliyyah). Tentunya ilmu hadist merupakan salah satu ilmu yang paling menekankan tradisi sanad, begitu juga dengan ilmu tafsir (Al-Quran) dan juga ilmu-ilmu lainnya yang sangat melihat keutuhan sanad dalam belajar.

\section{b. Tradisi Suhbah}

Pengkajian ilmu di Jami' al-Azhar dilihat dari beberapa perspektif yang baik lahir maupun batin, kedua-duanya memerlukan seorang guru untuk dapat bimbingan dan arahan supaya tidak terhempas ke lembah yang salah. Seperti pengajaran ilmu tasawuf yang melibatkan guru-murid sebagai dua elemen penting untuk mencapai prinsip-prinsip hubungan khusus. Prinsip-prinsip inilah yang diwujudkan melalui suhbah, ia merupakan hubungan yang terjalin kerana adanya inisiatif atau baiat dalam sesuatu tarekat (Isom Mudin, 2015: 403).

Di dalam Surah al-Taubah menunjukkan perkataan Nabi Muhammad SAW. kepada Abu Bakar dengan menyebutnya 'sahibih', sebagaiamana diketahui bahwa Abu Bakar memang seorang teman yang selalu bersama Rasulullah (Surah al-Taubah, 9:40). Artinya perkataan sahiba mengandung hubungan yang erat antara dua insan yang selalu berinteraksi sebagaimana hubungan persahabatan antara Rasulullah SAW. dengan para sahabat ketika beliau hidup. Rasulullah pula memanggil mereka dengan sebutan sahabat, bukannya murid (tilmidh atau talib) 


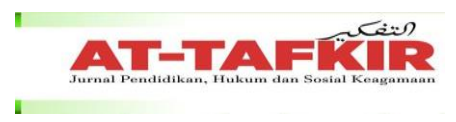

VOLUME 14 NOMOR 1 TAHUN 2021

P-ISSN : 1979-9357

E-ISSN : 2620-5858

yang pada dasarnya mereka mengambil ilmu daripada Nabi. Maka jelaslah, bahwa teladan dan kepemimpinan Rasulullah adalah kaedah duniawi yang berlaku dalam kehidupan sebenarnya dan memiliki peran penting untuk mencapai hakikat dan risalah Islam kepada dunia (Saeed Al-Olaqi, 2014). Begitulah realitas kehidupan pengajaran dan pembelajaran di Jami' Al-Azhar, mereka mengamalkan tradisi suhbah dalam mengkaji ilmu-ilmu keislaman sehingga lahir ulama-ulama dengan bidang kepakarannya masing-masing.

\section{c. Tradisi Ijazah}

Permulaan Islam belum dikenal dengan istilah ijazah, seseorang yang berkeinginan untuk belajar adalah berdasarkan minat dan keupayaannya dari segi biaya untuk mencari ilmu pengetahuan. Namun, keberadaan institusi pendidikan seperti al-Azhar telah memberikan nilai penting Ijazah. Al-Azhar mempraktekkan pemberian ijazah dari seorang guru kepada murid menurut bidang-bidang yang mereka pelajari dengan silsilah keilmuan sehingga dapat terhindar dari pengaruh kekacauan dan kesesatan ilmu yang diperoleh. Seorang murid yang memulaikan karier menjadi guru, maka ia mesti sanggup memuaskan para muridnya. Apabila tidak dapat dipenuhi semua persoalan yang diberikan, maka mereka akan kembali kepada guru yang semula lagi atau guru lainnya. Maka pemberian ijazah dipandang mampu menguasai dan mengamalkan ilmu-ilmu yang telah dipelajari serta telah menyelesaikan peringkat-peringkat ilmu tersebut (Maher, n.d.: 24).

\section{d. Tradisi Talaqqi}

Tradisi pendidikan yang paling awal dan sederhana dalam Islam adalah cara belajar dengan bentuk bulatan. Tradisi duduk berkeliling ini merupakan pengalaman pendidikan yang unik dalam Islam yang dikenali sebagai talaqqi. Tradisi ini juga diamalkan di Jami' al-Azhar sebagai tradisi keilmuan dalam hubungan guru-murid. Guru membacakan kitab yang ada ditangannya dari satu halaman ke halaman selanjutnya dalam setiap halaqah ilmu dengan penjelasan dan pendalaman terhadap nilai-nilai ilmu dalam kitab, bahkan guru tersebut adalah pengarang dari kitab itu sendiri (Syanawi, 2013: 60). Praktek ini terus diwujudkan di mana guru duduk di depan atau dinding atau tiang, dan murid membentuk separuh bulatan di hadapannya. Sementara itu, bulatan yang dibentuk adalah menurut peringkat, murid yang lebih cerdas maka ia akan duduk lebih dekat dengan guru, ataupun dengan murid yang paling menonjol. Begitu pula, apabila ada ulama yang berkunjung ke majlis tersebut maka murid yang paling menonjol juga akan duduk di sebelahnya. Terdapat juga tempat dari halaqah itu, yang selalu disediakan untuk pengunjung-pengunjung (tamu) yang mendatangi pengajian ilmu tersebut (Muhammad al-Bahi, 1964: 236-240; Mehdi Nakosteen, 1964: 45).

Halaqah ilmu seperti di atas telah dipraktekkan oleh ulama-ulama Islam dengan terus melazimi halaqah gurunya walaupun ia telah mencapai tahap keilmuan yang tinggi. Secara tidak langsung, ia terlibat dengan pengajaran yang berkelanjutan dengan muridnya sebagaimana yang diamalkan oleh Abu Hanifah. Beliau menunjukkan ketokohannya dalam pendidikan baik kepada guru maupun murid-muridnya (Mamat, 2013). Begitulah kenyataan yang berlaku di Jami' alAzhar, sebagian murid menuntut ilmu untuk menjaga tradisi talaqqi ataupun

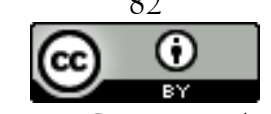

This work is licensed under a $\underline{\text { Creative Commons Attribution } 4.0 \text { International License }}$ 


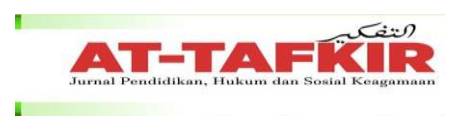

VOLUME 14 NOMOR 1 TAHUN 2021

P-ISSN : 1979-9357

E-ISSN : 2620-5858

mencari tempat yang tenang bagi pengkajian ilmu (Rabbat, 1996: 63). Talaqqi menunjukkan bahwa guru sebagai mentor dan murid sebagai anak didik yang diberikan ilmu agama, tuntunan adab/akhlak, motivasi, arahan, dan lainnya baik secara intelektual maupun spiritual.

\section{e. Interaksi Sosial Guru-Murid dalam Pendidikan}

Tradisi-tradisi yang dipraktekkan guru-murid di Jami' al-Azhar diatur dengan baik menurut golongan yang telah ditentukan. Sejak abad pertengahan murid di Jami' al-Azhar dibagi kepada dua golongan: 1) golongan yang tinggal di kediaman (asrama). 2) golongan yang tinggal di luar kediaman. Pada bagian tersebut terdapat ruwak-ruwak dan harat-harat (Maher, n.d.: 25), yang masih dijaga namanya sampai sekarang. Pada ruwak-ruwak tersebuk diadakan pengkajian, pelajaran, zikir, perdebatan (diskusi ilmiah) serta seminar-seminar. Pada masa itu jumlah ruwak mencapai 26 ruwak, dan jumlah harat pula mencapai 15 harat. Sementara itu, nama yang diberikan untuk ruwak tersebut terbagi kepada tiga bagian yaitu menurut jenis bangsa, mazhab dan kawasan dari kalangan murid (Maher, n.d.: 26).

Proses pengajaran dan pembelajaran dpraktekkan pada masing-masing ruwak dengan pengkajian ilmu agama dan bahasa yang paling diutamakan. Sehingga al-Azhar mencapai puncak kegemilangan pada abad pertengahan dan ia senantiasa muncul dan menonjol daripada pusat pendidikan lainnya. Ilmu-ilmu agama dari dahulu sampai sekarang juga menduduki tempat yang paling utama ('Anan, 1958: 57). Tidak heran apabila al-Azhar memiliki keistimewaan tersendiri, begitu juga seluruh gerakan ilmiah dan pemikiran di kalangan bangsa-bangsa yang kuat tidak terlepas dari pengkajian ilmu agama terutama prkatek hubungan gurumurid dengan berbagai tradisi.

Bagi menjaga dan memelihara alam keilmuan yang berkelanjutan, al-Azhar bertahan dengan memanfaatkan biaya yang berasal dari wakaf, baik wakaf umum maupun khusus. Ketika Kerajaan Fathimiyah berkuasa, ia mempunyai satu bagian khusus untuk wakaf yang dikelola oleh Mufti kerajaan. Sumber biaya ini, kemudian berkembang luas pada masa Kerajaan Mamluk dan menjadi sumber biaya yang subur bagi al-Azhar. Selain itu, terdapat hadiah dan sedekah yang berupa mata uang dan benda berharga. Kebiasaannya uang itu diberikan oleh para pendengar dan dermawan kepada guru atau muballigh yang memberikan kuliah dalam majelis kajian ilmu. Sehingga para guru atau muballigh mendapatkan bagian yang banyak dari uang ini. Tetapi sebagiannya diserahkan kepada al-Azhar untuk diberikan kepada murid-murid yang fakir. Sehingga Al-Azhar mempunyai saham daripada sedekah ini yang dinamakan dengan "Mal an-Najwi" yaitu pemberian guru dari sedekah para dermawan yang jumlahnya tiga dirham. Terdapat juga sedekah yang diberikan oleh para khalifah dan pembesar-pembesar kerajaan dengan berbagai macam jenisnya baik pakaian, makanan, roti dan sebagainya yang diberikan kepada murid-murid dan fakir miskin di al-Azhar pada musim-musim tertentu (Maher, n.d.: 18-19).

Sumber keuangan dari wakaf, hadiah maupun sedekah terus menerus berkembang dang diatur dengan baik oleh Syeikh al-Azhar. Saham ini yang kemudian membantu guru-murid untuk meneruskan pengkajian, menunaikan

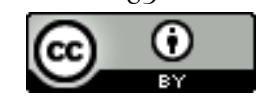

This work is licensed under a $\underline{\text { Creative Commons Attribution } 4.0 \text { International License }}$ 


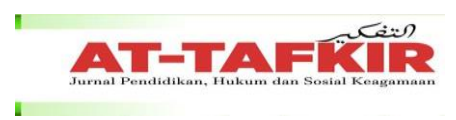

VOLUME 14 NOMOR 1 TAHUN 2021

P-ISSN : 1979-9357

E-ISSN : 2620-5858

tugas agama dan keilmuan yang senantiasa mengamalkan tradisi pengajaran dan pembelajaran dengan penuh keikhlasan dari setiap generasi ke generasi selanjutnya. Dengan demikian, tradisi suhbah, ijazah dan talaqqi terus dipraktekkan dengan baik dan ia tidak terlepas dari hubungan sosial dengan berbagai dukungan materil seperti kenyataan diatas. Hubungan moril dan materil yang diamalkan tersebut dapat memenuhi keperluan guru-murid dalam pengajaran dan pembelajaran maupun kehidupan mereka masing-masing.

\section{KESIMPULAN}

Jami' al-Azhar telah berperan sebagai pusat peradaban ilmu baik dalam sejarah Islam maupun sepanjang masa sampai sekarang. Ia tidak terlepas dari hubungan guru-murid yang senantiasa berkhidmat untuk ilmu pengetahuan dengan berbagai tradisi yang mempunyai nilai-nilai tersendiri. Permulaan pengajaran ilmu diadakan oleh Ya'qub ibn Killis dirumahnya, kemudian seiring perjalanan pengajian halaqah-halaqah tersebut, beliau meminta Khalifah al-'Aziz Billah Nizar Abu Mansur untuk meningkatkan status al-Azhar sebagai sebuah alJami'ah (universiti) yang dibiayai sepenuhnya oleh kerajaan. Memang awalnya bertujuan sebagai propaganda golongan Syi'ah, tetapi dalam perkembangannya telah menjadi pusat pemikiran dan pengkajian semua kalangan dengan menghimpun guru-murid sehingga menjadi ulama dan ahli politik yang menaungi negara dengan baik. Realita ini merupakan keutuhan hubungan guru-murid dalam menjaga agama dan negara. Hubungan kedua-duanya dalam pendidikan di Jami' alAzhar sehingga melahirkan kurikulum dalam pengkajian ilmu agama maupun sains.

Justru itu, hubungan guru-murid telah menggambarkan tradisi-tradisi pengkajian ilmu yang diamalkan sepanjang abad, termasuk menjaga autoritas ilmu dari generasi ke generasi selanjutnya. Antara tradisi yang dipraktekkan ialah sanand, suhbah, ijazah, dan talaqqi.

1. Tradisi sanad merupakan hubungan guru-murid bagi melihat keabsahan dan memastikan kesahihan ilmu yang disampaikan sehingga melahirkan susunan ilmu yang bersilsilah dan berautoritas.

2. Tradisi suhbah merupakan nilai hubungan guru-murid yang mencakup spiritual dalam keilmuan sehingga hakikatnya adalah ibadah kepada Allah SWT. semata-mata.

3. Tradisi ijazah menandakan pengakuan ilmu seorang murid, bahwa ilmu tersebut benar-benar didapati dari silsilah yang amanah serta mencegah daripada segala kesalahan dan kebimbangan.

4. Tradisi talaqqi pula menunjukkan keupayaan menerima ilmu dalam keadaan apapun untuk mendengarkan syarahan guru secara langsung yang dituntut kesabaran dan keikhlasan demi mendapatkan keberkahan ilmu dari kitab yang ditulis oleh gurunya sendiri ataupun kitab yang lainnya.

Berbagai hubungan tersebut dapat disimpulkan bahwa proses pengkajian ilmu adalah melalui silsilah keilmuan dan hubungan mentor. Kedua aspek ini mengesahkan bahwa tradisi hubungan guru-murid dipraktekkan di institusi pendidikan Islam secara utuh. Sehingga peradaban Islam di Jami' al-Azhar terus memberikan kontribusi sepanjang masa walaupun tiada sumber biaya yang pasti.

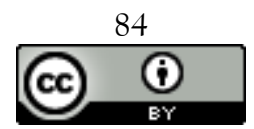

This work is licensed under a Creative Commons Attribution 4.0 International License 
P-ISSN : 1979-9357

E-ISSN : 2620-5858

Namun, sistem wakaf yang dijalankan telah memberikan manfaat yang besar bagi guru-murid secara berkelanjutan. Oleh yang demikian, kuncinya niat yang ikhlas dan amanah ilmu yang harus dijunjung sampai kapanpun. Hakikatnya hubungan guru-murid berpangkal kepada akhlak dan adab yang semata-mata untuk mencapai keutamaan agama dan meraih kebahagiaan dunia-akhirat serta mengharap keridhaan Allah SWT.

\section{DAFTAR PUSTAKA}

'Anan, M. A. (1958). Tarikh Jami' al-Azhar. Kaherah: Matba'ah Lajnah al-Ta'lif wa alTarjamah wa al-Nasyr.

Abaza, M. (1991). Some Research Notes on Living Conditions and Perceptions among Indonesian Students in Cairo. Journal of Southeast Asian Studies, 22(2), 347-360.

Abu Fida’ Ismail Ibn Kathir. (1997). al-Bidayah wa al-Nihayah (Abdullah Abdul Muhsin al-Turki (ed.)). Hajar.

Ahmad Sobri Salamon. (1988). Azhar and Politics. al-Rahmaniah.

Al-Dhahabi. (1984). Siyar al-'Alam al-Nubala' (17th ed.). Mu'assah al-Risalah.

Al-Qathan, M. (2007). Mabahist fi Ulum Al-Hadith (5th ed.). Maktabah Wahbah.

Al-Shallaabi, A. M. M. (2006). Al-Daulah al-Fathimiyyah. Mu'assasah Iqra'.

Al-Tahhan, M. (1985). Taysir Musthalah al-Hadith (7th ed.). Haramain.

Albo, M., \& Meital, Y. (2014). The Independent Path of Shaykh al-Azhar 'Abd alḤalīm Maḥmūd. Die Welt Des Islams, 54(2), 159-182.

Ali Ibrahim Hasan. (1963). Tarikh Jauhar al-Shiqili. Maktabah al-Nahdhah alMishriyyah.

Ali Khitab 'Atiyyah. (1947). Al-Ta'lim fi Misr fial-'Asr al-Fatimi al-Awwal. Dar al-Fikr al-Arabi.

Badawiy, 'Abd al-Rahman. (1977). Manahij al-Bats al-'Tlmiy (3rd ed.). Wakalah alMathbu'at.

Balwi, M. A. W. F. M., Sarif, S., \& Lubis, A. (2018). Authority Delegation In Organization: Lessons From 7th Century - Early Islamic Era. Jurnal AlTamaddun, 13(1), 1-11.

Barry Gower. (1997). Scientific Method: An Historical and Philosophical Introduction. Routledge.

Crecelius, D. (1966). Al-Azhar in the Revolution. Middle East Journal, 20(No. 1 Winter), 31-49.

Fadzlullah Hj. Shuib. (1995). Kecemerlangan Ilmu dalam Sejarah dan Tamadun Islam: penginstitusian ilmu di zaman Abbasiyah 750-1258 M. Pustaka Warisan.

Ghanem, H. (2016). The Arab Spring Five Years Later. Brookings Institution Press.

Gillbert J. Garraghan. (1946). A Guide to Historical Method. Fordham University Press.

Gubara, D. E. M. (2012). Al-Azhar in the Bibliographic Imagination. Journal of Arabic Literature, 43 No. 2/3 (Arabic Literature, Criticism and Intellectual Thought from the Nahdiah to the Present), 299-335.

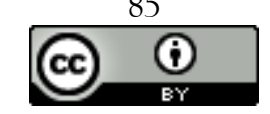

This work is licensed under a Creative Commons Attribution 4.0 International License 
P-ISSN : 1979-9357

E-ISSN : 2620-5858

Haris, A. H. (2014). Kaherah Sebagai Pusat Percetakan Karya Melayu-Islam, 1880An hingga 1960-An. Jurnal Al-Tamaddun, 9 No. 1, 15-31.

Ibn Khalikan. (1978). Wafiyat al-'Ayan wa Anba’u Abna'i al-Zaman (I. Abbas (ed.); 1st ed.). Dar Shadir.

Jasmi, K. A., \& Noh, M. A. C. (2013). Sejarah, Kaedah, Serta Model Pengajaran dan Pembelajaran Al-Quran. Remedial and Enrichment Workshop for Teaching and Learning Quran SRA JAWI, Oktober 2013, 1-17.

Lubis, S. A. (2012). Islamic Education Toward The Era of Social Change: Effort in Enhancing The Quality. Jurnal Al-Tamaddun, 7(1), 107-108.

Maher, S. (n.d.). Rentetan Penyelidikan Islam al-Azhar, Arti dan Kebudayaan (terj. R. H. Sjazli (ed.)). S.O.P. Press.

Mamat, M. A. (2013). Ketokohan Imam Abu Hanifah Al-Nu'Man (M.150 H/767 M) Dalam Bidang Pendidikan. Jurnal Al-Tamaddun, 8(2), 4-5.

Mehdi Nakosteen. (1964). History of Islamic Origin of Western Education A.D. 800-1350 with an Introduction to Medieval Muslimeducation. University of Colorado Press.

Mohd. Majid Konting. (1994). Kaedah Penyelidikan Pendidikan (3rd ed.). Dewan Bahasa dan Pustaka.

Mubarak, A. B. (n.d.). Min al-Khuthath al-Taufiqiyah al-Jadidah li al-Misr al-Qahirah wa Madaniha wa Biladiha al-Qadimah al-Syahirah. Matba'ah al-Kubra al-Amiriyah.

Mudin, M. I. (2015). Suhbah: Relasi Mursyid dan Murid dalam Pendidikan Spiritual Tarekat. Tsaqafah: Jurnal Peradaban Islam, 11(2), 399-416.

Muhammad al-Bahi. (1964). al-Azhar: Tarikhuhu wa tatawwuruhu. Wizarat al-Awqaf wa Syu'un al-Azhar.

Nur al-Din Itr. (1997). Manhaj al-Naqdi fi al-Ulum al-Hadith. Damsyik: Dar al-Fikr.

Rabbat, N. (1996). Al-Azhar Mosque: An Architectural Chronicle of Cairo's History. Muqarnas, 13, 45-67.

Rozali, E. A., \& Rahman, Z. A. (2017). Kecemerlangan Futuhat Islamiyyah Era Khulafa' Al-Rashidin. Jurnal Al-Tamaddun, 12(2), 25-40.

Saeed Al-Olaqi, F. M. T. (2014). The Prophet Muhammad's Leadership. Jurnal AlTamaddun, 9(1), 32-44.

Shalabi, A. (1954). Tarikh al-Tarbiyyah al-Islamiyyah. Maktabah al-Nahdhah alMishriyyah.

Syanawi, A. A. M. (2013). Al-Azhar: Jami'an wa Jami'ah. Maktabah al-Aglo alMisriyyah.

Taqi al-Din Ahmad ibn Ali Al-Maqrizi. (1997). Al-Khitat al-Maqriziah (M. Zainuhum \& M. Al-Syarqawi (eds.); 2nd ed.). Maktabah Madbuli.

Zeghal, M. (1999). Religion and Politics in Egypt: The Ulema of al-Azhar, Radical Islam, and the State (1952-1994). International Journal of Middle East Studies, 31, No. 3, 371-399.

\section{Acknowledgment}

We would like to acknowledge the financial support provided by University of Malaya under the Equitable Society Research Cluster (ESRC) research grant RP023A-15SBS.

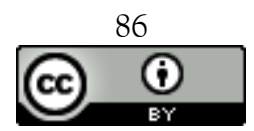

This work is licensed under a Creative Commons Attribution 4.0 International License 